American Journal of Animal and Veterinary Sciences 5 (3): 175-179, 2010

ISSN 1557-4555

(C) 2010 Science Publications

\title{
Ghrelin Gene Expression in Broiler Proventriculus Tissue are Changed by Feed Restriction, Different Dietary Energy and Protein Levels
}

\author{
${ }^{1}$ Shokoufe Ghazanfari, ${ }^{2}$ Mohammad Reza Nassiry, ${ }^{2}$ Mojtaba Tahmoorespur, \\ ${ }^{1}$ Abdolreza Salehi and ${ }^{2}$ Karim Nobari \\ ${ }^{1}$ Department of Animal Science, Aburaihan College, Tehran University, Tehran, Iran \\ ${ }^{2}$ Department of Animal Science, College of Agriculture, \\ Ferdowsi University of Mashhad, Mashhad, Iran,
}

\begin{abstract}
Problem statement: The aim of this study was to investigate the effects of feed restriction and different energy and protein contents of diet on ghrelin gene expression in broiler chicken. Approach: Feeding programs consisted of ad libitum and feed restriction, two energy levels (3100 and $2800 \mathrm{kcal} \mathrm{ME} \mathrm{kg}^{-1}$ ) and three protein levels (22.3, 19.3 and 16.3\% CP). Feed restriction was applied during 22-32 days of age. Proventriculus samples were collected at 21, 32 and 49 days of age. Ghrelin mRNA expression in proventriculus tissue was quantitate using Real Time quantitative PCR. Results: We found that ghrelin gene expression was increased in restricted chicks compared with those fed ad libitum at 32 days of age $(\mathrm{p}=0.09)$ but feed restriction had no effect on ghrelin gene expression at 49 days of age. A positive response in ghrelin gene expression was achieved by decreasing energy level in the diet at 21 days of age $(\mathrm{p}<0.07)$ and at 32 days of age $(\mathrm{p}<0.05)$. Also, we showed that dietary protein had no effect on ghrelin gene expression, whereas there was a tendency for an increase in ghrelin gene expression as protein decreased at total period. Conclusion: The present study, we investigated the effects of feed restriction and different energy and protein contents of the diet on ghrelin gene expression in broiler chicken. We have characterized chicken ghrelin cDNA in proventriculus tissue in broiler chicken. We also found that ghrelin gene expression is differently suppressed by diet manipulations. Additional studies are necessary to investigate the role of nutrition on ghrelin gene expression in proventriculus tissue in broiler chicken.
\end{abstract}

Key words: Feed restriction, energy, protein and ghrelin gene expression

\section{INTRODUCTION}

Chicken ghrelin was isolated from the proventriculus as endogenous ligand for the growth hormone secretagogue receptor (Kojima et al., 1999), which contains 26 amino acids with the third serine residue from the $\mathrm{N}$-terminus of the mature peptide being acylated with n-octonoic or n-decanoic acid (Kaiya et al., 2002). Ghrelin-producing cells have also been detected in the arcuate nuclei of the rat hypothalamus, which is a feeding control center (Kojima et al., 1999; Cowley et al., 2003). Therefore, ghrelin is thought to have a physiological role in meal initiation by acting as a hunger signal (Cummings et al., 2001). Also, ghrelin affects feeding, gastrointestinal function, energy metabolism and cardiovascular function (Kaiya et al., 2002). However, it should be emphasized that the final growth expression is the result of interactions between nutritional, environmental and genetic factors interacting with endocrine secretions. The purpose of this study was to determine the effect of feed restriction on ghrelin mRNA expression in proventriculus tissue in broiler chicken. There is no a study on the effect of dietary energy and protein levels on ghrelin gene expression in broiler chicken. Thus, this experiment was conducted to determine whether different dietary energy and protein levels alters ghrelin mRNA expression in broiler chicks.

\section{MATERIALS AND METHODS}

Animals and housing: This experiment took place at Poultry Research Station and biotechnology laboratory in Ferdowsi University of Mashhad, Iran, 2009.

Five hundred and seventy six, old Ross male broiler chicks were randomly allocated in equal numbers in 48 floor pens. The six diets were prepared daily and diets were fed from 1-49 days of age.

Corresponding Author: Shokoufe Ghazanfari, Department of Animal Science, Aburaihan College, Tehran University, Tehran, Iran Tel: +989151226890 Fax: +982923040907 
American J. Animal \& Vet. Sci., 5 (3): 175-179, 2010

Table 1: Feed ingredients and composition of experimental diets (0-49 days of age)

\begin{tabular}{|c|c|c|c|c|c|c|}
\hline \multirow[b]{2}{*}{ Ingredients (\%) } & \multicolumn{6}{|c|}{ Treatment diets } \\
\hline & 1 & 2 & 3 & 4 & 5 & 6 \\
\hline Corn & 54.50 & 61.87 & 69.38 & 51.98 & 56.38 & 61.73 \\
\hline Soybean meal $44 \%$ & 28.60 & 24.92 & 21.00 & 34.83 & 25.17 & 19.80 \\
\hline Corn gluten & 7.95 & 4.71 & 1.61 & 3.00 & 3.00 & 0.57 \\
\hline Vegetable oil & 3.50 & 3.00 & 2.46 & 1.00 & 1.00 & 1.00 \\
\hline Wheat bran & 1.50 & 1.50 & 1.50 & 5.67 & 10.89 & 13.28 \\
\hline Dicalcium phosphate & 1.69 & 1.74 & 1.79 & 1.32 & 1.39 & 1.44 \\
\hline Limestone & 1.17 & 1.21 & 1.24 & 1.16 & 1.17 & 1.20 \\
\hline Vit Min. Premix ${ }^{1}$ & 0.50 & 0.50 & 0.50 & 0.50 & 0.50 & 0.50 \\
\hline Salt & 0.44 & 0.44 & 0.44 & 0.41 & 0.41 & 0.40 \\
\hline DL-Methionine & 0.09 & 0.08 & 0.07 & 0.13 & 0.09 & 0.08 \\
\hline L-Lysine & 0.06 & 0.03 & 0.01 & - & - & - \\
\hline Total & 100.00 & 100.00 & 100.00 & 100.00 & 100.00 & 100.00 \\
\hline \multicolumn{7}{|l|}{ Compositions (calculated) } \\
\hline $\mathrm{ME}\left(\mathrm{kcal} \mathrm{kg}^{-1}\right)$ & 3100.00 & 3100.00 & 3100.00 & 2800.00 & 2800.00 & 2800.00 \\
\hline Crud protein $(\%)$ & 22.30 & 19.30 & 16.30 & 22.30 & 19.30 & 16.30 \\
\hline Calcium (\%) & 0.97 & 0.97 & 0.97 & 0.88 & 0.88 & 0.88 \\
\hline Available P (\%) & 0.44 & 0.44 & 0.44 & 0.39 & 0.39 & 0.39 \\
\hline Sodium (\%) & 0.19 & 0.19 & 0.19 & 0.18 & 0.18 & 0.18 \\
\hline Arginine (\%) & 1.27 & 1.12 & 0.97 & 1.41 & 1.18 & 1.01 \\
\hline Lysine (\%) & 1.07 & 0.92 & 0.78 & 1.14 & 0.92 & 0.78 \\
\hline Methionine + Cystine $(\%)$ & 0.87 & 0.75 & 0.64 & 0.87 & 0.75 & 0.64 \\
\hline
\end{tabular}

$500 \mathrm{mg}$, Mn, 76 mg; Zn, $66 \mathrm{mg}$; Fe, 40 mg; Cu, 4 mg; I, $0.64 \mathrm{mg}$; Se, $0.2 \mathrm{mg}$

Table 2: Experimental treatments

\begin{tabular}{|c|c|c|c|c|c|c|}
\hline \multirow[b]{2}{*}{ Treatment } & \multicolumn{6}{|c|}{ Without feed restriction } \\
\hline & 1 (control) & 2 & 3 & 4 & 5 & 6 \\
\hline Energy level (Kcal ME kg $\left.{ }^{-1}\right)$ & 3100 & 3100 & 3100 & 2800 & 2800 & 2800 \\
\hline \multirow[t]{3}{*}{ Protein level (\%CP) } & 22.3 & 19.3 & 16.3 & 22.3 & 19.3 & 16.3 \\
\hline & \multicolumn{6}{|c|}{ With feed restriction (22-32 days of age) } \\
\hline & 7 & 8 & 9 & 10 & 11 & 12 \\
\hline Energy level (Kcal ME kg $\left.{ }^{-1}\right)$ & 3100 & 3100 & 3100 & 2800 & 2800 & 2800 \\
\hline Protein level (\%CP) & 22.3 & 19.3 & 16.3 & 22.3 & 19.3 & 16.3 \\
\hline
\end{tabular}

Note: This table showed experimental treatments with and without feed restriction. Feed restriction was applied during 22-32 days of age. After the feed restriction period, the birds were fed ad libitum until end of the experiment (49 days of age)

Feed ingredients and composition of experimental diets were exhibited in Table 1. Broiler chickens were assigned into two feeding programs from 22 until 32 days of age. One feeding program was given free access to feed (ad libitum) and the other fed a limited amount of feed (restricted). The restricted birds were fed ad libitum every other day and that no restriction was placed on the birds during the days feed was provided. Feed restriction treatments were applied during 22-32 days of age. After the feed restriction period, the birds were fed ad libitum until end of the experiment (49 days of age). Also, broilers were assigned randomly to

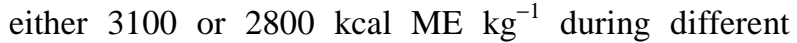
periods (0-49 days of age). Protein levels were set to $22.3,19.3$ and $16.3 \%$ during different periods (0-49 days of age). According to the treatment groups, the chickens were arranged in a $2 \times 2 \times 3$ factorial arrangements in a completely randomized design experiment (two feeding programs, two energy levels and three protein levels) at 22-32 and 32-49 days of age but there was not feed restriction during 0-21 days of age thereby chickens were arranged $2 \times 3$ factorial arrangements in a completely randomized design experimental at 0-21 days of age (two energy levels and three protein levels). Experimental treatments had exhibited in Table 2. Each treatment group consisted of 4 replicates of 12 chickens each. The chickens were randomly allocated in cages and light was provided 24 hours daily at 0-49 days of age. At 21, 32 and 49 days of age, one chicken from each replicate of each treatment that had body weight close to the mean replicate was selected and then slaughtered to collect proventriculus tissue for evaluation ghrelin gene expression. Proventriculus samples were frozen in 
liquid nitrogen and stored at $-80^{\circ} \mathrm{C}$. Experimental diets were formulated to provide similar nutrients content according to the broilers nutrients requirement except for protein and energy levels (Table 1). The experimental diets were based on corn-soybean meal containing vegetable oil. Chickens had free access to fresh water throughout the experiment.

RNA extraction and reverse transcription-PCR assay for ghrelin gene expression: Total RNA was isolated from the chicken proventriculus tissue using Trizol reagent procedure (Invitrogen/Life Technologies, Isogene Co, Russian) according to the manufacturer's instructions. The quantity and integrity of isolated RNA were determined for each sample by using both UV absorbances (260/280) as well as by $1 \%$ agarose gel electrophoresis. Then RNA samples were stored at $-80^{\circ} \mathrm{C}$ until use. RNA was treated with DNase using Ambion's DNA-free kit (Fermentas/Life Science/Isogene Co, Russian) to remove any possible DNA contamination. Samples were stored at $-80^{\circ} \mathrm{C}$ until use. Reverse Transcription (RT) Polymerase Chain Reaction (PCR) was performed using a RevertAid first strand cDNA synthesis kit (Fermentas/Life Science/Isogene Co, Russian) containing RNA (5 $\mu \mathrm{g}), 20$ pmol gene-specific primer and DEPC-treated water. The mixture incubated at $65^{\circ} \mathrm{C}$ for $5 \mathrm{~min}$. Then $5 \times$ reaction buffer, $20 \mathrm{u} \mu \mathrm{L}^{-1}$ RiboLock RNase Inhibitor, $10 \mathrm{~mm}$ dNTP mix and $200 \mathrm{u} \mu \mathrm{L}^{-1}$ RevertAid M-MuLV Reverse Transcriptase added to above mixture. After incubation $\left(42^{\circ} \mathrm{C}, 60 \mathrm{~min}\right)$, the mixture was heated $\left(70^{\circ} \mathrm{C}, 5 \mathrm{~min}\right)$ and then stored at $-20^{\circ} \mathrm{C}$.

A chicken ghrelin fragment (203 bp) was amplified with a sense primer (5-CCT TGG GAC AGA AAC TGC TC-3') and an anti-sense primer (5'CAC CAA TTT CAA AAG GAA CG -3') reported by Richards et al. (2006). Chicken $18 \mathrm{~S}$ as an internal control (fragment size: 148 bp): Sense primer (5'-CGC GTG CAT TTA TCA GAC CA-3') and an anti-sense primer (5-'ACC CGT GGT CAC CAT GGT A-3') reported (Paczoska-Eliasiewicz et al., 2003). All the PCR products were sequenced.

Ghrelin mRNA quantitation in proventriculus tissue by real-time RT-PCR: A master mix containing SYBR Green PCR Master Mix (Applied Biosystems, Warrington, United Kingdom), 10 pmol forward primer, 10 pmol reverse primer, cDNA, water was prepared to perform real-time PCR. The following PCR protocol was used on the ABI (Applied Biosystems)
7300 apparatus. Initial steps contain $2 \mathrm{~min}$ at $50^{\circ} \mathrm{C}$ and $10 \mathrm{~min}$ at $95^{\circ} \mathrm{C}$, followed by two-step amplification program $\left(15 \mathrm{sec}\right.$ at $95^{\circ} \mathrm{C}$ followed by $1 \mathrm{~min}$ at $\left.61^{\circ} \mathrm{C}\right)$ repeated 40 times. Quantification was performed using ABI integrated software as previously described (Pfaffle, 2001). 18S ribosomal RNA was chosen as a reference gene. Each PCR run included a no template control and replicates of control and unknown samples. Runs were performed in duplicate. The chicken ghrelin (203 bp) and 18S (148 bp) cDNA were run on a $1 \%$ agarose gel and visualized by etidium bromide staining using a UV illuminatore.

Statistical analysis: All analyses were conducted using General Linear Model procedures (GLM) of SAS. Significant differences among individual group means were determined with Duncan's multiple range test (SAS Institute, 2001). Relative expression of Ghrelin mRNA determined using sample delta CT to control delta CT ratio method and then were conducted using GLM of SAS.

\section{RESULTS}

Ghrelin mRNA expression: Ghrelin mRNA expression in the broiler chicken proventriculus was detected (Fig. 1). The specificity of the amplified cDNA fragment of chicken ghrelin was verified by agarose gel $1 \%$ and sequencing PCR product ghrelin fragment (203 bp).

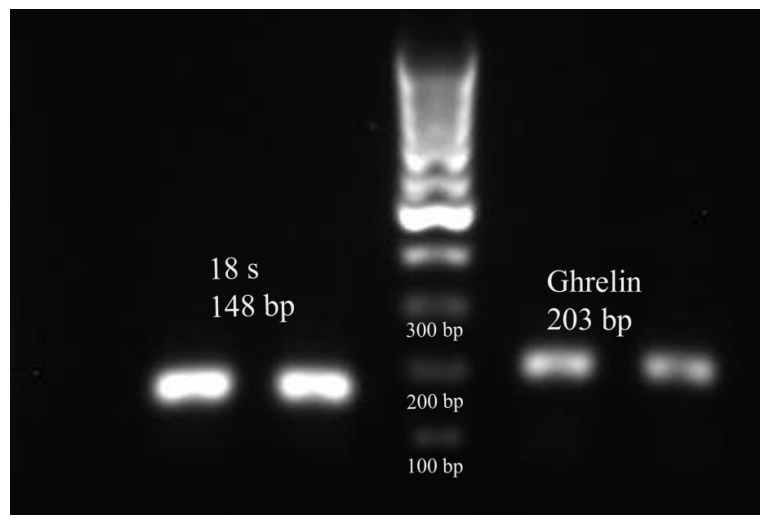

Fig. 1: Expression of ghrelin and 18S ribosomal RNA in proventriculus in broiler chicken. RT-PCR amplified fragments of ghrelin and $18 \mathrm{~S}$ ribosomal RNA were separated by gel electrophoresis (1\%) and produced a 203 and 148 bp fragment of the ghrelin and 18S RNA, respectively 
American J. Animal \& Vet. Sci., 5 (3): 175-179, 2010

Table 3: Effect of feed restriction and dietary energy and protein levels on ghrelin gene expression in broiler chicken

\begin{tabular}{|c|c|c|c|c|c|c|c|}
\hline \multirow[b]{2}{*}{ - } & \multicolumn{2}{|c|}{ Feeding program } & \multicolumn{2}{|c|}{ Energy $\left(\mathrm{kcal} \mathrm{ME} \mathrm{kg}^{-1}\right)$} & \multicolumn{3}{|l|}{ Protein $(\%)$} \\
\hline & $\begin{array}{l}\text { Feed restricted } \\
(\mathrm{n}=24)\end{array}$ & $\begin{array}{l}\text { ad libitum } \\
(\mathrm{n}=24)\end{array}$ & $\begin{array}{l}3100 \\
(\mathrm{n}=24)\end{array}$ & $\begin{array}{l}2800 \\
(\mathrm{n}=24)\end{array}$ & $\begin{array}{l}22.3 \\
(\mathrm{n}=16)\end{array}$ & $\begin{array}{l}19.3 \\
(\mathrm{n}=16)\end{array}$ & $\begin{array}{l}16.3 \\
(\mathrm{n}=16)\end{array}$ \\
\hline$\overline{\text { Delta ghrelin/delta } 18 \mathrm{~S} \text { ratio, } 21 \text { day }}$ & - & - & $0.94 \pm 0.04$ & $1.06 \pm 0.04$ & $1.01 \pm 0.05^{\mathrm{ab}}$ & $0.92 \pm 0.05^{\mathrm{b}}$ & $1.09 \pm 0.05^{\mathrm{a}}$ \\
\hline Delta ghrelin/delta $18 \mathrm{~S}$ ratio, 32 day & $1.34 \pm 0.06$ & $1.19 \pm 0.06$ & $1.17 \pm 0.06^{\mathrm{b}}$ & $1.36 \pm 0.06^{\mathrm{a}}$ & $1.24 \pm 0.07$ & $1.28 \pm 0.07$ & $1.27 \pm 0.07$ \\
\hline Delta ghrelin/delta $18 \mathrm{~S}$ ratio, 49 day & $0.91 \pm 0.06$ & $0.98 \pm 0.06$ & $0.98 \pm 0.06$ & $0.92 \pm 0.06$ & $0.91 \pm 0.07$ & $0.92 \pm 0.07$ & $1.01 \pm 0.07$ \\
\hline
\end{tabular}

Note: All values are mean \pm SEM, Means within rows with different letter superscripts are significantly different $(p<0.05)$; there is no feed restriction at 0-21 days of age thereby there is no feed restriction data at 0-21 days of age. It explained in materials and methods section

Effect of feed restriction, dietrary energy and protein levels on ghrelin gene expression in proventriculus tissue in broiler chicken: The effects of feed restriction, dietrary energy and protein levels on ghrelin gene expression of broiler chicken are presented in Table 3.

We looked at the effect of feed restriction and refeeding on ghrelin mRNA in the proventriculus tissue. Ghrelin gene expression increased in restricted birds compared with those fed ad libitum at 32 days of age $(\mathrm{p}<0.1)$.

There is no a study on the effect of dietary energy and protein levels on ghrelin gene expression in broiler chicken. Decreasing dietary energy increased ghrelin gene expression at $21(\mathrm{p}<0.07)$ and $32(\mathrm{p}<0.05)$ days of age. Dietary protein had no effect on ghrelin gene expression, whereas there was a tendency for an increase in ghrelin gene expression as protein decreased at total period.

\section{DISCUSSION}

This is the first report to demonstrate ghrelin gene expression influence by different dietary energy and protein levels in broiler chicken.

The purpose of this experiment was twofold (1) to further study the use of a two-step RT-PCR in a real time mode to determine ghrelin gene expression in proventriculus tissue and (2) to extend our studies on the relationship of feed restriction and dietary protein and energy status with ghrelin gene expression in broiler.

Results of the present study are in agreement with Kaiya et al. (2002) who reported ghrelin gene expression in proventriculus in 8-day-old chickens using RT-PCR. Wada et al. (2003) observed ghrelin mRNA expression only in the proventriculus of newly hatched Leghorn chicks, whereas in adult chickens, mRNA expression was also detected in proventriculus and duodenum. This is similar to the tissue expression patterns reported previously for 8-week-old White Leghorn chickens (Tanaka et al., 2003) and 10 day-old broiler chicks (Geelissen et al., 2003).

Also, Richards et al. (2006) determined changes in ghrelin mRNA levels in proventriculus, pancreas and brain under different energy balance states created by fasting and refeeding of 3 week-old broiler chickens. They showed fasting (negative energy balance) elevated ghrelin gene expression in proventriculus tissue. In present experiment, expression of ghrelin mRNA in the proventriculus tissue returned to the control levels after refeeding at 49 days of age. This was an expected observation, which agreement with Kaiya et al. (2007) and Richards et al. (2006) who have reported the expression of ghrelin mRNA in the proventriculus returned to the control levels after reseeding. This study demonstrated that the ghrelin mRNA expression in proventriculus were altered in response to feeding states in broiler chicken in a similar manner as in rat and human, suggesting a role of ghrelin as a hunger signal.

Effect of diet manipulation on ghrelin gene expression was studied only in rat and human. Asakawa et al. (2003) indicated gastric ghrelin mRNA expression during fasting was increased by a high fat diet. Therefore, these findings show that ghrelin gene expression is differently suppressed by diet manipulations. Stomach ghrelin expression parallels ghrelin secretion. Monteleone et al. (2003) indicated that plasma ghrelin changes were significantly associated with hunger changes. Beck et al. (2002) had shown that ghrelin plasma concentration was low when a high-fat diet is ingested for a long period of time and that it increased when the amount of carbohydrates in the diet increased. The levels of ghrelin were therefore linked to the fat content of the diet and the low ghrelin levels observed in rats ingesting a high fat diet may contribute to limit the energy intake provided by this calorie-rich food. Ghrelin secretion was therefore very sensitive to the diet composition.

\section{CONCLUSION}

In summary, we investigated the effects of feed restriction and different energy and protein contents of the diet on ghrelin gene expression in broiler chicken. We have characterized chicken ghrelin cDNA in proventriculus tissue in broiler chicken. We also found that ghrelin gene expression is differently suppressed by diet manipulations. Additional studies are necessary 
to investigate the role of nutrition on ghrelin gene expression in proventriculus tissue in broiler chicken.

\section{ACKNOWLEDGEMENT}

This study was supported by a Grant-in-Aid for Scientific Research from the Ferdowsi University of Mashhad for my Ph.D. dissertation. We thank Dr. Nassiri and Dr. Tahmoorespuran for developing the concept and designing the experiments. We are also grateful to Dr. Salehi for conducting the analyses. We are also grateful to Dr. Ghazanfari and Dr. Nobari for carrying out the experimental design.

\section{REFERENCES}

Asakawa, A., A. Inui, T. Kaga, G. Katsuura and M. Fujimiya et al., 2003. Antagonism of ghrelin receptor reduces food intake an body weight gain in mice. Gut, 52: 947-952. PMID: 1773718

Beck, B., N. Musse and A. Stricker-Krongrad, 2002. Ghrelin, macronutrient intake and dietary preferences in Long-Evans rats. Biochem. Biophys. Res. Commun., 292: 1031-1035. DOI: 10.1006/BBRC.2002.6737

Cowley, M.A., R.G. Smith, S. Diano, M. Tschop and N. Pronchuk, 2003. The distribution and mechanism of action of ghrelin in the CNS demonstrates a novel hypothalamic circuit regulating energy homeostasis. Neuron, 37: 649-661. PMID: 12597862

Cummings, D.E., J.Q. Purnell, R.S. Frayo, K. Schmidova, and B.E. Wisse et al., 2001. A preprandial rise in plasma ghrelin levels suggests a role in meal initiation in humans. Diabetes, 50: 1714-1719. DOI: 10.2337/diabetes.50.8.1714

Geelissen, S.M.E., I.M.E. Beck, V.M. Darras and E.R. Kuhn, 2003. Distribution and regulation of chicken growth hormone secretagogue receptor isoforms. Gen. Comput. Endocrinol., 134: 167-174. PMID: 14511987

Kaiya, H., S.V.D. Geyten, M. Kojima, H. Hosoda and Y. Kitajima et al., 2002. Chicken Ghrelin: Purification, cDNA cloning and biological activity. Endocrinology, 143: 3454-3463. DOI: 10.1210/en.2002-220255
Kaiya, H., V.M. Darras and K.J. Kangawa, 2007. Ghrelin in birds: Its structure, distribution and function. J. Poult. Sci., 44: 1-18. DOI: $10.2141 /$ jpsa.44.1

Kojima, M., H. Hosoda, Y. Date, M. Nakazato and H. Matsuo et al., 1999. Ghrelin is a growthhormone-releasing acylated peptide from stomach. Nature, 402: 656-660. DOI: 10.1038/45230

Monteleone, P., R. Bencivenga, N. Longobardi, C. Serritella and M. Maj, 2003. Differential responses of circulating ghrelin to high-fat or highcarbohydrate meal in healthy women. J. Clin. Endocrinol. Metab., 88: 5510-5514. DOI: 10.1210/jc.2003-030797

Paczoska-Eliasiewicz, H.E., A. Gertler, M. Proszkowiec, J. Proudman and A. Hrabia et al., 2003. Attenuation by leptin of the effects of fasting on ovarian function in hens (Gallus domesticus). Reproduction, 126: 739-751. DOI: 10.1530/rep.0.1260739

Pfaffle, M.W., 2001. A new mathematical model for relative quantification in real-time RT-PCR. Nucleic Acids Res., 29: e45-e45. PMID: 11328886

Richards, M.P., S.M. Poch and J.P. McMurty, 2006. Characterization of turkey and chicken ghrelin genes and regulation of ghre.lin and ghrelin receptor mRNA levels in broiler chichens. J. General Compar. Endocrinology, 145: 298-310. DOI: 10.1016/j.ygcen.2005.09.013

SAS Institute, 2000. SAS Use's Guide: Statistics. Version 8 Edn., SAS Institute Inc., Cary, NC., ISBN: 10: 158025599X, pp: 576.

Tanaka, M., T. Miyazaki, I. Yamamoto, N. Nakai and Y. Ohta et al., 2003. Molecular characterization of chicken growth hormone secretagogue receptor gene. Gen. Comp. Endocrinol., 134: 198-202. DOI: 10.1016/S0016-6480(03)00247-8

Wada, R., I. Sakata, H. Kaiya, K. Nakamura and Y. Hayashi et al., 2003. Existence of ghrelinimmunopositive and-expressing cells in the proventriculus of the hatching and adult chicken. Regul. Peptid., 111: 123-128. DOI: 10.1016/S0167-0115(02)00265-3 